\title{
Effect of exogenous LH pulses on the fate of the first dominant follicle in postpartum beef cows nursing calves
}

\author{
P. Duffy ${ }^{1}$, M. A. Crowe ${ }^{2}$, M. P. Boland ${ }^{1}$ and J. F. Roche ${ }^{2}$ \\ ${ }^{1}$ Faculty of Agriculture, University College Dublin, Lyons Research Farm, Newcastle, Co. Dublin, Ireland; and ${ }^{2}$ Faculty of Veterinary \\ Medicine, University College Dublin, Ballsbridge, Dublin 4, Ireland
}

\begin{abstract}
Prolonged postpartum anoestrus in beef cows is due to failure of early dominant follicles to ovulate. It is hypothesized that this failure to ovulate is due to inadequate LH pulse frequency. The objective of this study was to determine whether administration of hourly LH pulses would cause the first dominant follicle to ovulate. In Expt 1, 16 cows received either saline $(n=8)$ or porcine $\mathrm{LH}\left(\mathrm{pLH} ; 50 \mu \mathrm{g} \mathrm{h}^{-1} ; n=8\right)$ as hourly pulses for $3-5$ days from the second day of dominance of the first dominant follicle (day 0). In Expt 2,21 cows received either saline $(n=7)$, or $50 \mu \mathrm{g} \mathrm{pLH}(n=7)$ or $100 \mu \mathrm{g} \mathrm{pLH}(n=7)$ as hourly pulses for 3 days. Appropriate ovarian scanning and assays of blood samples were carried out. In Expt 1, the number of dominant follicles that underwent atresia was not affected by increasing the number of LH pulses, but the duration of dominance (days) of the first and second dominant follicles and maximum size $(\mathrm{mm})$ of the second dominant follicle were increased $(P<0.05)$. Oestradiol concentrations were higher $(P<$ $0.05)$ in cows given hourly pLH pulses $\left(3.1 \pm 1.2 \mathrm{pg} \mathrm{ml}^{-1}\right)$ compared with controls $(1.2 \pm$ $\left.0.2 \mathrm{pg} \mathrm{ml}^{-1}\right)$. Four of eight treated cows had an anovulatory LH surge. The number of follicle waves to first ovulation was not different $(P<0.05)$ between control $(4.6 \pm 0.9)$ and pLH treated cows $(3.9 \pm 0.5)$. In Expt 2, four of seven cows given pulses of $100 \mu \mathrm{g}$ $\mathrm{pLH} \mathrm{h}^{-1}$ ovulated the first dominant follicle, and the interval from calving to first ovulation was decreased $(P<0.05)$. In the remaining three cows, the duration of dominance of the first dominant follicle was increased $(P<0.005)$, the maximum size of the first dominant follicle was greater $(P<0.05)$, and the interval (days) from the start of infusion to new wave emergence was greater $(P<0.05)$ compared with cows that failed to ovulate in either the $50 \mu \mathrm{g} \mathrm{pLH} \mathrm{h}{ }^{-1}$ or control treatments. In conclusion, hourly pulses of pLH from day 1 after dominance of the first dominant follicle in postpartum beef cows can either prolong dominance or induce it to ovulate. This finding supports the hypothesis that LH pulse frequency is a key determinant of the fate of the dominant follicle in the early postpartum period.
\end{abstract}

\section{Introduction}

The number of calves produced annually is a key component of high productivity in beef cows. However, prolonged postpartum (PP) anoestrus has an adverse effect on the size of the annual calf production of beef cows. A 12 month calving interval is biologically efficient; however, Williams (1990) estimated that only $50-70 \%$ of beef cows in the US achieve this, and the remaining cows either have an intercalving interval $>365$ days, or fail to produce a calf in that year.

The emergence of the first follicle wave occurs within 10-14 days (Murphy et al., 1990) of parturition and is associated with the early resumption of recurrent FSH increases (Crowe et al., 1998), presumably due to the abrupt withdrawal of the negative feedback effect of oestrogens and

Received 18 February 1999. progesterone before parturition. Prolonged postpartum anoestrus in beef cows is due to failure of these early dominant follicles to ovulate (Murphy et al., 1990; Stagg et al., 1995). Dairy cows that are not under nutritional stress generally ovulate the first dominant follicle (Savio et al., 1990), in contrast to a mean of $3.2 \pm 0.2$ dominant follicles to first ovulation in beef suckler cows with a good body condition score (Murphy et al., 1990). However, beef cows in poor body condition can have 8-14 follicle waves before the first ovulation (Stagg et al., 1995). Failure of the early dominant follicle to ovulate is thought to be due to inadequate LH pulse frequency (Roche et al., 1992; Williams and Griffith, 1995; Stagg et al., 1998), which results in low androgen production in the follicle (Fortune, 1986) and inadequate oestradiol positive feedback to induce a preovulatory gonadotrophin surge (Peters et al., 1985). In support of this hypothesis, a single injection of a GnRH analogue (20 $\mu \mathrm{g}$ Buserelin) 
administered during the growing phase of the first dominant follicle in beef cows consistently induced ovulation of that follicle (Crowe et al., 1993), demonstrating that the first dominant follicle post partum is capable of ovulation if it receives an appropriate gonadotrophin surge.

Therefore, the objective of these studies was to determine whether hourly LH pulses of similar magnitude to those detected in the follicular phase of the oestrous cycle (Rahe et al., 1980) would stimulate sufficient oestrogen secretion, after selection of the first dominant follicle to induce a gonadotrophin surge and ovulation.

\section{Materials and Methods}

\section{Animals and treatments}

Experiment 1. Sixteen postpartum Limousin $\times$ Friesian spring-calving cows in their first to sixth lactation were used. Cows were housed indoors until calving and fed a maintenance diet of grass silage with a mineral supplement. After calving, the cows and calves were at pasture. They were blocked on the basis of parity, body weight, body condition score and calving date, and assigned at calving to one of two treatments: (i) $0.84 \mathrm{ml}$ saline $\mathrm{h}^{-1}$ (controls; $n=8$ ); (ii) $50 \mu \mathrm{g}$ of porcine LH (pLH; Lutropin, Vetrepharm, Canada) $\mathrm{h}^{-1}$ in $0.84 \mathrm{ml}$ saline $(n=8)$. pLH or saline pulses were delivered once an hour through a cannula inserted into the right jugular vein using an autosyringe pulse infusion pump (Glaxo model AS6H) from 1 day (day 0) after detection of the first dominant follicle post partum by ovarian ultrasound scanning once a day.

Experiment 2. Twenty-one postpartum Limousin $\times$ Friesian spring-calving cows in their first to seventh lactation were used in year 2 and managed as described for Expt 1. They were assigned to treatments as follows: (i) $0.84 \mathrm{ml}$ saline $\mathrm{h}^{-1}$ (controls; $n=7$ ); (ii) $50 \mu \mathrm{gLH} \mathrm{h}^{-1}$ in $0.84 \mathrm{ml}$ saline $(n=7)$; and (iii) $100 \mu \mathrm{g} \mathrm{pH} \mathrm{h}^{-1}$ in $0.84 \mathrm{ml}$ saline $(n=7)$. pLH or saline pulses were delivered once an hour for 3 days as in Expt 1 .

\section{Ultrasound examination of ovaries}

In both experiments, the ovaries of each cow were scanned once a day from day 7 or 8 post partum until the first ovulation, and then once at day 4 after ovulation to verify the formation of a corpus luteum, using real-time ultrasonography (Dynamic Imaging, Livingston) with a 7.5 $\mathrm{MHz}$ transrectal linear probe as described by Murphy et al. (1990). A dominant follicle was defined as the largest follicle $\geq 10 \mathrm{~mm}$ in diameter that was at least $2 \mathrm{~mm}$ larger than all other follicles present on either ovary.

\section{Blood sampling}

In both experiments, blood samples were collected once a day for progesterone assays from day 7 post partum until either behavioural oestrus was detected or until 25 days after the first ovulation to confirm ovulation and formation of the corpus luteum, and to determine the duration of the lifespan of the first corpus luteum post partum. Blood samples were collected twice a day to determine oestradiol concentrations from day 0 to day 5 after infusion of LH. Blood samples for LH assay were collected through a cannula inserted into the left jugular vein at 15 min intervals for 8 (day -1 relative to $\mathrm{LH}$ infusion) or $6 \mathrm{~h}$ (days 0 and 2) to determine LH pulse frequency and amplitude during the LH infusion period. Blood samples were taken every $8 \mathrm{~h}$ from day 0 to day 2 of pLH infusion and subsequently every $4 \mathrm{~h}$ until day 5 after the start of the infusion period for determination of $\mathrm{FSH}$ and LH concentrations. After collection, blood samples were stored at room temperature for $1 \mathrm{~h}$ and at $4^{\circ} \mathrm{C}$ for $18-24 \mathrm{~h}$, and were centrifuged at $1614 \mathrm{~g}$ for $15 \mathrm{~min}$. Serum was decanted and stored at $-20^{\circ} \mathrm{C}$ until assayed.

\section{Hormone assays}

Progesterone concentrations were determined using the non-extraction radioimmunoassay described by Ronayne and Hynes (1990). Mean interassay coefficients of variation (CV; $n=4$ ) for samples containing $0.20,0.82$ and $2.44 \mathrm{ng}$ progesterone $\mathrm{ml}^{-1}$ were $14.0,15.9$ and $11.2 \%$, respectively. Intra-assay $\mathrm{CV}(n=9)$ for the same samples were 14.2, 7.4 and $8.5 \%$, respectively. The sensitivity of the assay was $0.03 \mathrm{ng}$ $\mathrm{ml}^{-1}$. Oestradiol concentrations were determined using the radioimmunoassay described by Prendiville et al. (1995). Mean interassay CV $(n=6)$ for samples containing $0.78,2.38$ and $5.89 \mathrm{pg}$ oestradiol ml $\mathrm{ml}^{-1}$ were 22.5, 15.6 and $19.1 \%$, respectively. Intra-assay $\mathrm{CV}(n=3)$ for the same samples were $11.8,14.1$ and $11.5 \%$, respectively. The sensitivity of the assay was $0.2 \mathrm{pg} \mathrm{ml}^{-1}$. LH concentrations were determined using the radioimmunoassay described by Cooke et al. (1997). Mean interassay $\mathrm{CV}(n=9)$ for samples containing 2.2, 6.5 and 10.2 ng LH ml${ }^{-1}$ were $11.6,12.1$ and $11.0 \%$, respectively. Intra-assay CV $(n=7)$ for the same samples were 9.5, 9.5 and $14.2 \%$, respectively. The sensitivity of the assay was $0.1 \mathrm{ng} \mathrm{ml}^{-1}$. FSH concentrations were determined using a heterologous radioimmunoassay described by Crowe et al. (1997) using NIDDK-anti-oFSH antibody (AFP-C5288113) and the bovine FSH standard preparation (USDA bFSH B1). Mean interassay CV $(n=4)$ for samples containing 16.6, 23.3 and 51.4 ng FSH $\mathrm{ml}^{-1}$ were $7.2,5.7$ and $7.9 \%$, respectively. Intra-assay CV $(n=3)$ for the same samples were 4.6, 5.3 and $9.3 \%$, respectively. The sensitivity of the assay was $1.6 \mathrm{ng} \mathrm{ml}^{-1}$.

\section{Statistical analyses}

Follicular data were analysed using ANOVA (Snedecor and Cochran, 1980). LH pulses were determined by PC-Pulsar pulse detection algorithm (Merriam and Wachter, 1982). The $G$ parameters used were: $\mathrm{G} 1=2.40, \mathrm{G} 2=2.00, \mathrm{G} 3=1.90, \mathrm{G} 4=$ $1.90, \mathrm{G} 5=1.90$. Comparisons between groups, on all hormone parameters, were made using ANOVA (Snedecor and Cochran, 1980). Proportions of cows that had an LH surge (LH concentration $>10 \mathrm{ng} \mathrm{ml}^{-1}$ for $>6 \mathrm{~h}$ ) and that ovulated were analysed using chi-squared analysis (Swinscow, 1996). 


\section{Results}

\section{Experiment 1}

Parameters before LH or saline infusion. After calving and before pLH infusion, mean body weight, body condition score (scale $0-5 ; 0=$ emaciated, $5=$ obese), and number of days post partum to the first day of infusion were not different for cows allocated to the different treatment groups (Table 1). There was no difference among treatments in the size of the first dominant follicle on the first day of infusion (Table 1).

LH pulse frequency. On day -1 , there was no difference between cows assigned to treatment groups, in the mean number of LH pulses $\mathrm{h}^{-1}(0.13 \pm 0.4$ and $0.21 \pm 0.3$ for control and $50 \mu \mathrm{gLH} \mathrm{h}^{-1}$ groups, respectively). However, more pulses were detected in cows treated with pLH on day 0 (0.9 $\pm 0.5 \mathrm{LH}$ pulses $\left.\mathrm{h}^{-1}\right)$ and day $2\left(0.8 \pm 0.4 \mathrm{LH}\right.$ pulses $\left.\mathrm{h}^{-1}\right)$ compared with control cows $(0.16 \pm 0.5$ and $0.26 \pm 0.4$ pulses $\mathrm{h}^{-1}$ on days 0 and 2 , respectively). The mean concentration of $\mathrm{LH}$ in the treated cows $\left(4.1 \pm 0.7 \mathrm{ng} \mathrm{ml}^{-1}\right)$ was higher $(P<$ $0.05)$ than in the controls $\left(1.4 \pm 0.3 \mathrm{ng} \mathrm{ml}^{-1}\right)$. The mean of the maximum LH concentration was higher $(P<0.05)$ in treated cows $\left(26.6 \pm 7.6 \mathrm{ng} \mathrm{ml}^{-1}\right)$ compared with controls $(5.1 \pm 2.0$ $\mathrm{ng} \mathrm{ml} \mathrm{m}^{-1}$ ) during the infusion period. Concentrations of $\mathrm{LH}$ were also higher $(P<0.05)$ in cows that had a subsequent $\mathrm{LH}$ surge $\left(46.5 \pm 0.9 \mathrm{ng} \mathrm{ml}^{-1}\right)$ compared with cows in the treated group that did not have an LH surge $\left(6.7 \pm 2.9 \mathrm{ng} \mathrm{ml}^{-1}\right)$.

Serum oestradiol concentrations. Mean oestradiol concentrations in control cows $\left(0.7 \pm 0.1 \mathrm{pg} \mathrm{ml}^{-1}\right)$ during the $\mathrm{pLH}$ infusion period were lower $(P<0.05)$ than in cows given $50 \mu \mathrm{g} \mathrm{pLH} \mathrm{h}{ }^{-1}\left(1.5 \pm 0.3 \mathrm{pg} \mathrm{ml}^{-1}\right)$. Peak concentrations of oestradiol in control cows $\left(1.2 \pm 0.2 \mathrm{pg} \mathrm{ml}^{-1}\right)$ during the $\mathrm{pLH}$ infusion period were lower $(P<0.05)$ than in cows given $50 \mu \mathrm{gLH} \mathrm{h}^{-1}\left(3.1 \pm 0.7 \mathrm{pg} \mathrm{ml}^{-1}\right)$ throughout the treatment period. For cows treated with $\mathrm{pLH}$, mean serum oestradiol concentrations $\left(2.1 \pm 0.4\right.$ versus $\left.1.19 \pm 0.2 \mathrm{pg} \mathrm{ml}^{-1}\right)$ and the mean of the maximum amplitude of oestradiol attained during the $\mathrm{pLH}$ infusion period $(4.5 \pm 0.8$ versus $1.7 \pm 0.2 \mathrm{pg}$ $\mathrm{ml}^{-1}$, respectively) were higher $(P<0.05)$ in cows that had an LH surge compared with those that did not have an LH surge.

Gonadotrophins. Four of eight cows given hourly $50 \mu \mathrm{g}$ pLH pulses had a subsequent LH and FSH surge, whereas none $(P<0.05)$ of the cows infused with saline had a surge between days 0 and 5 . There was no difference in mean serum FSH concentrations during the treatment period for pLH treated $\left(21 \pm 1.5 \mathrm{ng} \mathrm{ml}^{-1}\right)$ or control $\left(19 \pm 2.0 \mathrm{ng} \mathrm{ml}^{-1}\right)$ cows. There was also no difference in serum FSH concentrations between cows with $\left(24 \pm 2.3 \mathrm{ng} \mathrm{ml}^{-1}\right)$ or without $\left(18 \pm 0.4 \mathrm{ng} \mathrm{ml}^{-1}\right)$ an LH surge within the group treated with pLH.

Follicular dynamics and first ovulation. The duration of dominance of the first dominant follicle was greater $(P<$ 0.05 ) in cows given $50 \mu \mathrm{g} \mathrm{pLH} \mathrm{h}{ }^{-1}$ compared with controls. The maximum size of the first dominant follicle was greater $(P<0.05)$ and the interval from treatment to the first day of dominance of the second dominant follicle was greater $(P<$ 0.05 ) in the cows given pLH compared with control cows (Table 1). There was no effect of pLH infusion on the postpartum interval to first ovulation between control (38.2 \pm 6.4 days $)$ and treated cows ( $40.5 \pm 2.9$ days). There was also no effect of treatment on the number of follicle waves to first ovulation between control $(4.5 \pm 0.8)$ and treated cows $(4.0 \pm$ $0.5)$. After the first ovulation, all cows had a short oestrous cycle (9-12 days).

Table 1. Follicular dynamics in postpartum beef cows before, during and after hourly infusion of saline (controls) or $50 \mu \mathrm{g}$ porcine LH ( $\mathrm{pLH}$ ) for 3 days beginning on the day after detection of the first dominant follicle (DF1) (Expt1)

\begin{tabular}{lcc}
\hline Parameters & Control & $50 \mu g$ pLH h \\
\hline Pre-experimental parameters & & \\
$\quad$ Body weight (kg) & $510 \pm 27.4$ & $509 \pm 25.2$ \\
Body condition score (scale 0-5) & $2.7 \pm 0.2$ & $2.8 \pm 0.2$ \\
Postpartum interval to start of experiment (days) & $11.3 \pm 0.41$ & $11.5 \pm 0.57$ \\
Size of DF1 at start of infusion (mm) & $12.5 \pm 0.80$ & $11.8 \pm 0.59$ \\
Follicular parameters during LH infusion & & \\
Maximum size of DF1 (mm) & $14.3 \pm 1.42$ & $16.6 \pm 1.58$ \\
Interval from day 0 to maximum size of DF1 (days) & $2.3 \pm 0.3^{\mathrm{a}}$ & $6.4 \pm 1.5^{\mathrm{b}}$ \\
Duration of dominance of DF1 (days) & $3.4 \pm 0.6^{\mathrm{a}}$ & $7.6 \pm 1.25^{\mathrm{b}}$ \\
$\quad$ Duration of detection of DF1 (days) & $6.5 \pm 0.74^{\mathrm{a}}$ & $13.8 \pm 2.40^{\mathrm{b}}$ \\
Follicular parameters after LH infusion & & \\
$\quad$ Day 0 to next wave emergence (days) & $2.4 \pm 0.35^{\mathrm{a}}$ & $8.3 \pm 1.33^{\mathrm{b}}$ \\
Maximum size of DF2 (mm) & $14.0 \pm 0.61^{\mathrm{a}}$ & $20.0 \pm 1.61^{\mathrm{b}}$ \\
$\quad$ Duration of dominance of DF2 (days) & $3.6 \pm 0.6^{\mathrm{a}}$ & $7.4 \pm 1.3^{\mathrm{b}}$ \\
Duration of detection of DF2 (days) & $5.0 \pm 0.45^{\mathrm{a}}$ & $10.1 \pm 1.4^{\mathrm{b}}$ \\
\hline
\end{tabular}

Values are mean \pm SEM.

Day 0 is the first day of infusion of pLH.

${ }^{\mathrm{ab}}$ Within rows, values with different superscripts are significantly different $(P<0.05)$. 


\section{Experiment 2}

Parameters before LH or saline infusion. After calving and before $\mathrm{pLH}$ infusion, body weight, body condition score, and the number of days post partum to the first day of infusion was not different among cows assigned to the different treatment groups. There was no difference among treatments in the size of the first dominant follicle on the first day of infusion (Table 2).

LH pulse frequency and amplitude. On day -1 relative to the start of LH infusion, there was no difference among cows assigned to treatment groups in the mean number of $\mathrm{LH}$ pulses $\mathrm{h}^{-1}$ (Table 3). Infusion of hourly pLH pulses increased $(P<0.05)$ the number of LH pulses on days 0 and 2 compared with controls. There was no difference in LH pulse amplitude among treatments on day -1 relative to the start of LH infusions (Table 3). On days 0 and 2 of LH infusions, LH pulse amplitude was between 1.9- and 2.4-fold higher $(P<$ 0.03 ) in the cows infused with $100 \mu \mathrm{g} \mathrm{pLH} \mathrm{h}{ }^{-1}$ compared with those infused with $50 \mu \mathrm{g} \mathrm{pHHh}^{-1}$. Individual LH pulse profiles are presented (Fig. 1). Mean LH concentrations (1.6 \pm $0.2,4.09 \pm 1.3$ and $4.29 \pm 1.6 \mathrm{ng} \mathrm{ml}^{-1}$ for cows treated with saline, $50 \mu \mathrm{g} \mathrm{pLH} \mathrm{h}{ }^{-1}$ and $100 \mu \mathrm{g} \mathrm{pLH} \mathrm{h}{ }^{-1}$, respectively) and the mean of the maximum LH pulse amplitude $(2.3 \pm 0.4$, $25.8 \pm 5.9$ and $18.9 \pm 6.2 \mathrm{ng} \mathrm{ml}^{-1}$ for cows treated with saline, $50 \mathrm{pLH}_{\mu \mathrm{g} \mathrm{h}}^{-1}$ and $100 \mu \mathrm{g} \mathrm{pLH} \mathrm{h}{ }^{-1}$, respectively) were higher $(P<0.05)$ in cows treated with $\mathrm{pLH}$ than in controls during the treatment period. Mean LH concentrations and the mean of the peak LH concentration were higher $(P<0.05)$ in the treated cows that had an LH surge compared with those that did not have a LH surge (Table 4).

Serum oestradiol concentrations. The overall mean concentrations of oestradiol were higher $(P<0.05)$ in cows treated with $100 \mu \mathrm{g} \mathrm{pLH} \mathrm{h}{ }^{-1}\left(2.1 \pm 0.3 \mathrm{pg} \mathrm{ml}^{-1}\right)$ than in cows
Table 3. LH pulse frequency and amplitude before, during and after hourly infusion with either saline (controls) or 50 or $100 \mu \mathrm{g}$ porcine $\mathrm{LH}(\mathrm{pLH}) \mathrm{h}^{-1}$ for 3 days beginning on the day after detection of the first dominant follicle (Expt 2).

\begin{tabular}{|c|c|c|c|}
\hline Treatment & Control & $\begin{array}{c}50 \mu \mathrm{g} p \mathrm{pH} \\
\mathrm{LH} \mathrm{h}^{-1}\end{array}$ & $\begin{array}{c}100 \mu \mathrm{g} \mathrm{pLH} \\
\mathrm{LH} \mathrm{h}^{-1}\end{array}$ \\
\hline \multicolumn{4}{|c|}{$\begin{array}{l}\text { LH pulse frequency } \\
\left(\text { pulses } \mathrm{h}^{-1}\right)\end{array}$} \\
\hline Day -1 & $0.21 \pm 0.026$ & $0.21 \pm 0.026$ & $0.17 \pm 0.026$ \\
\hline Day 0 & $0.17 \pm 0.000^{a}$ & $0.81 \pm 0.037^{b}$ & $0.90 \pm 0.025^{b}$ \\
\hline Day 2 & $0.23 \pm 0.042^{\mathrm{a}}$ & $0.92 \pm 0.033^{b}$ & $0.911 \pm 0.028^{b}$ \\
\hline \multicolumn{4}{|c|}{$\begin{array}{l}\text { LH pulse amplitude } \\
\left(\mathrm{ng} \mathrm{ml}^{-1}\right)\end{array}$} \\
\hline Day -1 & $2.1 \pm 0.39$ & $2.4 \pm 0.36$ & $3.3 \pm 0.86$ \\
\hline Day 0 & $2.4 \pm 0.32^{\mathrm{a}}$ & $1.8 \pm 0.19^{b}$ & $3.4 \pm 0.05^{\mathrm{a}}$ \\
\hline Day 2 & $2.9 \pm 0.22^{\mathrm{ab}}$ & $1.7 \pm 0.14^{\mathrm{a}}$ & $4.0 \pm 0.75^{\mathrm{b}}$ \\
\hline
\end{tabular}

Values are mean \pm SEM.

Day 0 is the day on which infusion of pLH commenced.

${ }^{a b}$ Within rows, values with different superscripts are significantly different $(P<0.05)$.

treated with $50 \mu \mathrm{g} \mathrm{pLH} \mathrm{h}^{-1}\left(0.8 \pm 0.2 \mathrm{pg} \mathrm{ml}^{-1}\right)$ or controls $(0.7$ $\left.\pm 0.1 \mathrm{pg} \mathrm{ml}^{-1}\right)$. Peak oestradiol concentrations were higher $(P$ $<0.05)$ in cows treated with $100 \mu \mathrm{gLHh}^{-1}(3.4 \pm 0.3 \mathrm{pg}$ $\left.\mathrm{ml}^{-1}\right)$ than in cows treated with $50 \mu \mathrm{g} \mathrm{pLH} \mathrm{h}{ }^{-1}(1.4 \pm 0.2 \mathrm{pg}$ $\left.\mathrm{ml}^{-1}\right)$ or controls $\left(1.3 \pm 0.3 \mathrm{pg} \mathrm{ml}^{-1}\right)$. Within the cows treated with $\mathrm{pLH}$, mean serum oestradiol concentrations $(0.8 \pm 0.2$ and $0.6 \pm 0.1 \mathrm{pg} \mathrm{ml}^{-1}$ for cows treated with $50 \mu \mathrm{g} \mathrm{pLH} \mathrm{h}{ }^{-1}$ with and without an LH surge; and $2.15 \pm 0.6$ and $2.18 \pm 0.5$

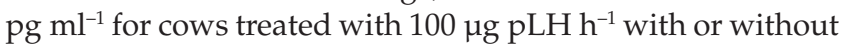
an LH surge) were not different between those that had and those that did not have an LH surge (Fig. 2).

Table 2. Follicular dynamics in postpartum beef cows before, during and after hourly infusion with either saline (controls) or 50 or $100 \mu \mathrm{g}$ porcine LH (pLH) for 3 days beginning on the day after detection of the first dominant follicle (Expt 2)

\begin{tabular}{|c|c|c|c|}
\hline Treatment & Control & $50 \mu \mathrm{g} \mathrm{pLH} \mathrm{h} \mathrm{h}^{-1}$ & $100 \mu \mathrm{g} \mathrm{pLH} \mathrm{h}{ }^{-1}$ \\
\hline \multicolumn{4}{|l|}{ Pre-experimental parameters } \\
\hline Body weight $(\mathrm{kg})$ & $564 \pm 17$ & $573 \pm 20$ & $577 \pm 21$ \\
\hline Body condition score (scale $0-5$ ) & $3.3 \pm 0.1$ & $3.4 \pm 0.1$ & $3.3 \pm 0.1$ \\
\hline Postpartum interval to detection of DF1 (days) & $10.9 \pm 0.5$ & $11.6 \pm 0.6$ & $11.1 \pm 0.9$ \\
\hline Size of DF1 at start of infusion (mm) & $11.0 \pm 0.6$ & $11.7 \pm 0.4$ & $12.4 \pm 0.6$ \\
\hline \multicolumn{4}{|l|}{ Follicle parameters during LH infusion } \\
\hline Maximum size of DF1 (mm) & $12.9 \pm 0.6^{\mathrm{a}}$ & $14.7 \pm 0.7^{\mathrm{ab}}$ & $17.4 \pm 1.3^{\mathrm{b}}$ \\
\hline Interval from day 0 to maximum size of DF1 (days) & $2.1 \pm 0.6$ & $3.3 \pm 0.6$ & $4.3 \pm 1.4$ \\
\hline Duration of dominance of DF1 (days) & $2.6 \pm 0.6^{\mathrm{a}}$ & $4.0 \pm 0.6^{\mathrm{a}}$ & $8.3 \pm 2.0^{\mathrm{b}}$ \\
\hline Duration of detection of DF1 (days) & $9.1 \pm 1.2$ & $9.9 \pm 0.7$ & $13.0 \pm 2.5$ \\
\hline \multicolumn{4}{|l|}{ Follicle parameters after LH infusion } \\
\hline Day 0 to next wave emergence (days) & $3.2 \pm 0.5^{\mathrm{a}}$ & $3.9 \pm 0.6^{\mathrm{ab}}$ & $6.3 \pm 1.7^{\mathrm{b}}$ \\
\hline Maximum size of DF2 $(\mathrm{mm})$ & $15.4 \pm 1.7$ & $17.4 \pm 0.9$ & $20.0 \pm 2.0$ \\
\hline Duration of dominance of DF2(days) & $3.0 \pm 1.2$ & $5.7 \pm 0.8$ & $6.5 \pm 3.5$ \\
\hline Duration of detection of DF2 (days) & $8.6 \pm 1.9$ & $13.0 \pm 1.4$ & $13.0 \pm 3.0$ \\
\hline
\end{tabular}

Values are mean \pm SEM.

Day 0 is the first day of infusion of $\mathrm{pLH}$.

${ }^{\mathrm{ab}}$ Within rows, values with different superscripts are significantly different $(P<0.05)$. 

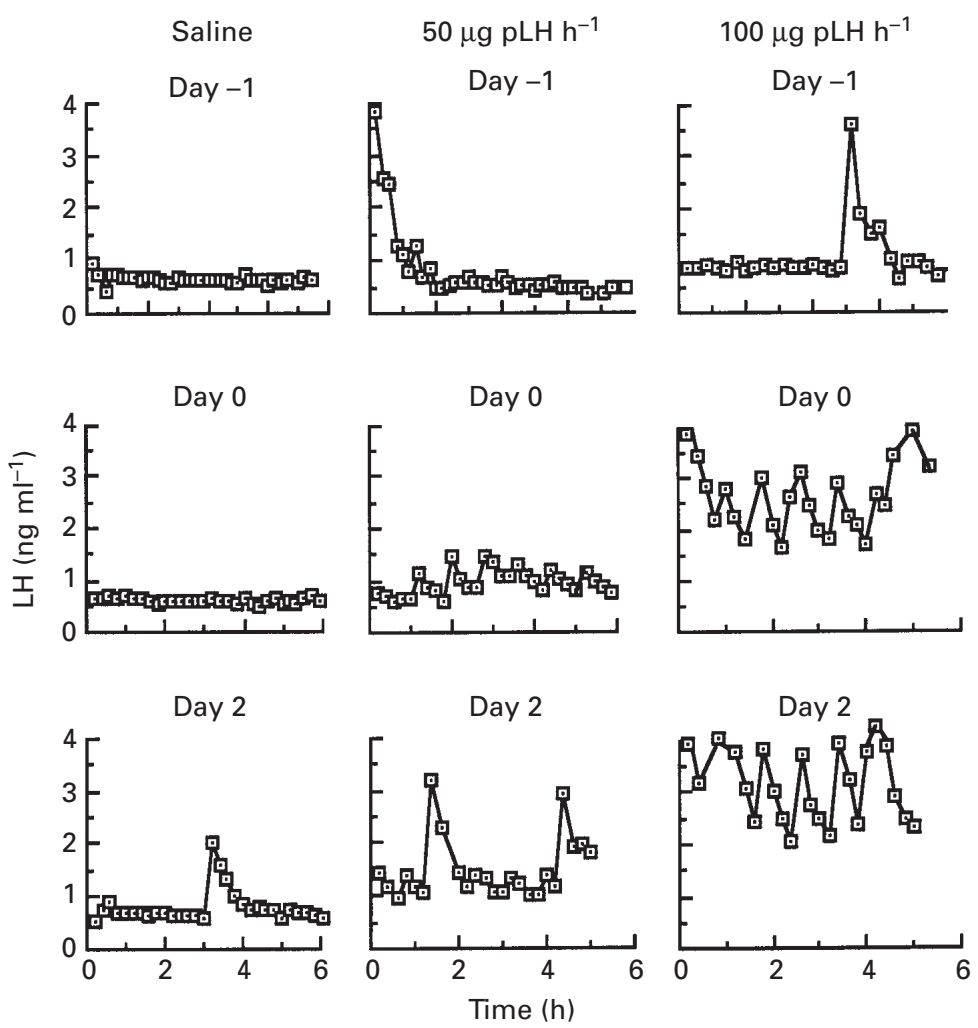

Fig. 1. LH profiles in representative postpartum beef suckler cows infused with either saline, $50 \mu \mathrm{g}$ porcine LH (pLH), or $100 \mu \mathrm{g}$ pLH every hour between days 10 and 13 post partum. Samples were collected every 15 min for $8 \mathrm{~h}$ on day -1 (day $0=$ first infusion) and for $6 \mathrm{~h}$ on days 0 and 2 .

Table 4. Overall mean \pm SEM and mean of the maximum serum LH concentrations in beef suckler cows with or without an LH surge after infusion of porcine LH during the growing period of the first dominant follicle post partum (Expt 2)

\begin{tabular}{lcc}
\hline Treatment & $\begin{array}{c}\text { Mean LH } \\
\left(\mathrm{ng} \mathrm{ml}^{-1}\right)\end{array}$ & $\begin{array}{c}\text { Maximum LH } \\
\left(\mathrm{ng} \mathrm{ml}^{-1}\right)\end{array}$ \\
\hline Saline & $1.6 \pm 0.2^{\mathrm{a}}$ & $2.3 \pm 0.4^{\mathrm{a}}$ \\
$50 \mu \mathrm{g} \mathrm{h}^{-1}$ with LH surge & $7.6 \pm 1.3^{\mathrm{b}}$ & $48.8 \pm 11.9^{\mathrm{b}}$ \\
$50 \mu \mathrm{g} \mathrm{h}^{-1}$ without LH surge & $1.8 \pm 0.3^{\mathrm{a}}$ & $2.7 \pm 0.5^{\mathrm{a}}$ \\
$100 \mu \mathrm{g} \mathrm{h}^{-1}$ with LH surge & $5.8 \pm 1.6^{\mathrm{b}}$ & $33.9 \pm 13.4^{\mathrm{b}}$ \\
$100 \mu \mathrm{g} \mathrm{h}^{-1}$ without LH surge & $2.8 \pm 0.6^{\mathrm{a}}$ & $4.1 \pm 0.4^{\mathrm{a}}$ \\
\hline
\end{tabular}

${ }^{a b}$ Within columns, values with different superscripts are significantly different $(P<0.05)$.

Gonadotrophins. Five of seven cows receiving $50 \mu \mathrm{g} \mathrm{pLH} \mathrm{h}{ }^{-1}$ and 4 of 7 cows receiving $100 \mu \mathrm{g} \mathrm{pLH} \mathrm{h}^{-1}$ had a subsequent LH and FSH surge, whereas none $(P<0.05)$ of the cows infused with saline had a surge between days 0 and 5 . There was no difference in mean serum FSH concentrations during the treatment period $(15.8 \pm 3.2,14.2 \pm 2.4$ and $15.2 \pm 0.9 \mathrm{ng}$ $\mathrm{ml}^{-1}$ for cows treated with saline, $50 \mu \mathrm{g} \mathrm{pLH} \mathrm{h}^{-1}$ and $100 \mu \mathrm{g}$ $\mathrm{pLH} \mathrm{h}^{-1}$, respectively). There was also no difference in serum FSH concentrations within the groups treated with pLH between cows with or without an LH surge $(14.7 \pm 3.1$ and $15.2 \pm 2.7 \mathrm{ng} \mathrm{ml}^{-1}$ for cows treated with $50 \mu \mathrm{g} \mathrm{pHH} \mathrm{h}^{-1}$ and $14.5 \pm 2.4$ and $13.2 \pm 4.0 \mathrm{ng} \mathrm{ml}^{-1}$ for cows treated with $100 \mu \mathrm{g}$ $\mathrm{pLH} \mathrm{h}^{-1}$; Figs 2 and 3).

Progesterone concentrations. Progesterone concentrations increased $\left(>0.3 \mathrm{ng} \mathrm{m}^{-1}\right)$ for 7-12 days in all cows that did not ovulate the first dominant follicle, when they ovulated a subsequent dominant follicle, and these cows were deemed to have a short cycle. In cows ovulating the first dominant follicle within 2 days of the end of treatment, progesterone concentrations increased $\left(>0.3 \mathrm{ng} \mathrm{ml}^{-1}\right)$ for $>15$ days.

Follicular dynamics and first ovulation. The duration of dominance of the first dominant follicle was greater $(P<0.005)$ in cows given $100 \mu \mathrm{g} \mathrm{pLH} \mathrm{h}{ }^{-1}$ that failed to ovulate the first dominant follicle compared with the other groups. The maximum size of the first dominant follicle was greater $(P<$ 0.05) in the cows infused with $100 \mu \mathrm{gLH} \mathrm{h}^{-1}$ than in cows in the other two treatment groups. The interval from the start of pLH infusion to emergence of the second dominant follicle was 
(a)

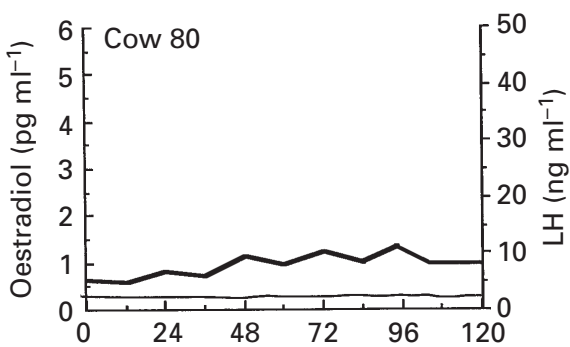

(b)
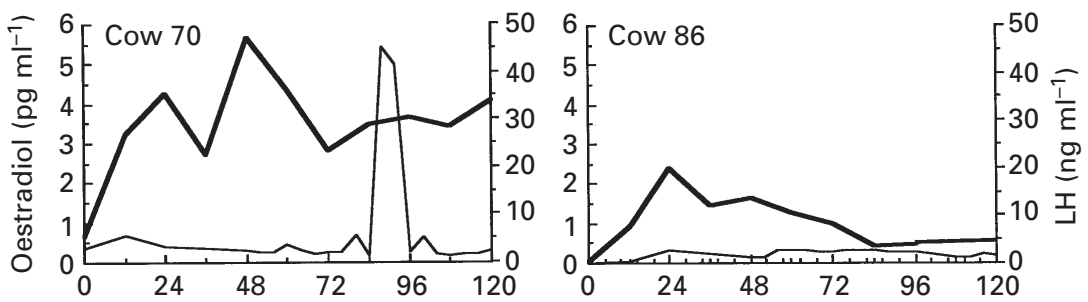

(c)
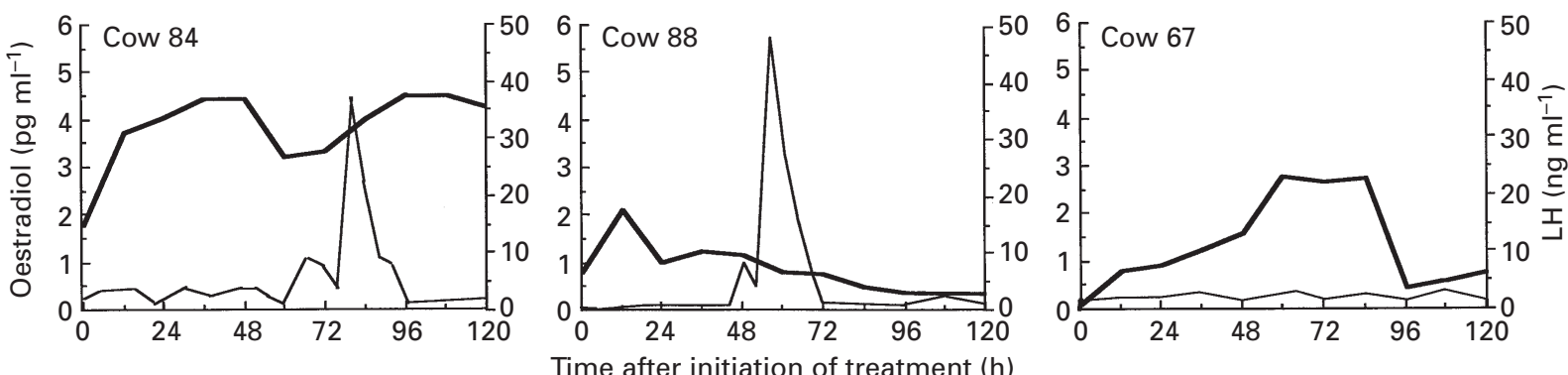

Fig. 2. LH (-) and oestradiol (—) concentrations in (a) a control cow and cows treated with (b) $50 \mu$ g porcine LH (pLH) $\mathrm{h}^{-1}$ or (c) 100 $\mu \mathrm{g} \mathrm{pLH} \mathrm{h}^{-1}$. (a) Cow 80 ovulated the third postpartum dominant follicle; (b) cow 70 had an LH surge but failed to ovulate until the second postpartum dominant follicle; cow 86 had no LH surge and failed to ovulate until the fourth postpartum dominant follicle; (c) cow 84 ovulated the first postpartum dominant follicle after an LH surge; cow 88 had an LH surge but ovulated the fourth dominant follicle post partum; and cow 67 had no LH surge and ovulated the third postpartum dominant follicle.

greater $(P<0.05)$ in the cows infused with $100 \mu \mathrm{g} \mathrm{pLH} \mathrm{h}^{-1}$ with anovulatory first dominant follicle compared with the other two groups (Table 2). In three cows infused with $100 \mu \mathrm{g}$ pLH $\mathrm{h}^{-1}$, the first dominant follicle ovulated within 2 days of the end of the infusion period, which was followed by an oestrous cycle of normal duration (on the basis of progesterone concentrations), whereas one cow ovulated the first dominant follicle 15 days after the start of pLH treatment and this ovulation was followed by a short oestrous cycle. Thus, the interval from calving to first ovulation was shortened in those cows that ovulated within 2 days of the end of infusion with $100 \mu \mathrm{gLH} \mathrm{h}^{-1}(16.5 \pm 1.8$ days). In the remaining cows receiving $100 \mu \mathrm{gLHh}^{-1}$ the postpartum interval to first ovulation was prolonged ( $44.0 \pm 3.8$ days) compared with the saline infused cows (29.2 \pm 2.1 days), and was followed by a short oestrous cycle (Fig. 4).

\section{Discussion}

This study demonstrates that increasing LH pulse frequency from one pulse every $6-8 \mathrm{~h}$ to one pulse every $1 \mathrm{~h}$ altered follicular dynamics in the early postpartum period in beef cows nursing calves, and either caused the first dominant follicle post partum to ovulate or prolonged its duration of dominance. In cattle, $\mathrm{LH}$ is critical for growth of dominant follicles beyond $7 \mathrm{~mm}$ in diameter (Gong et al., 1997). When LH pulse frequency is low, the dominant follicle grows, shows dominance for a few days and regresses, as is typical during the luteal phase of a normal oestrous cycle. Conversely, high LH pulse frequency stimulates oestradiol production from follicles, leading to a preovulatory LH surge and ovulation. When LH frequency is intermediate, the growth of dominant follicles is prolonged (Savio et al., 1993). The fact that increasing LH pulse frequency to one pulse per hour in the current study either caused prolonged dominance or ovulation of the first postpartum dominant follicle shows that the fate of the dominant follicle in cows is modulated by LH pulse frequency.

Oestrogen-active dominant follicles on days 3-7 of the oestrous cycle increased LH binding to the thecal cells, and on day 7 there is increased LH but not FSH binding to the granulosa cells (Ireland and Roche, 1982). In addition, the period of dominance of the dominant follicle in heifers given sub-luteal phase concentrations of progesterone (intermediate LH; Stock and Fortune, 1993) can be significantly prolonged 
(a)

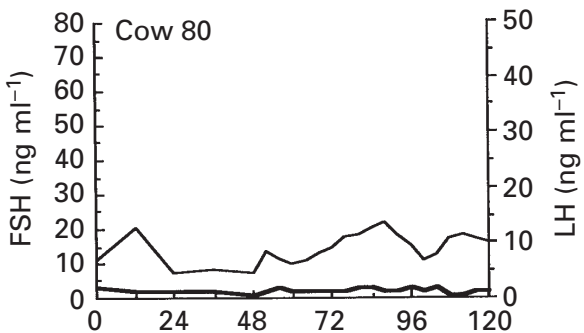

(b)

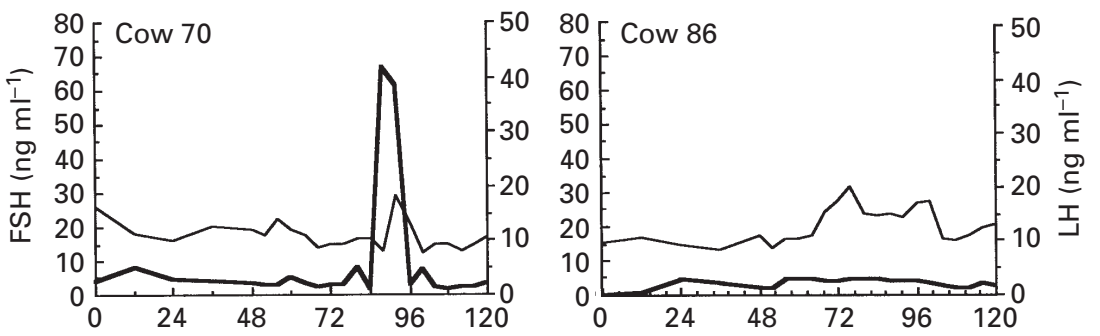

(c)
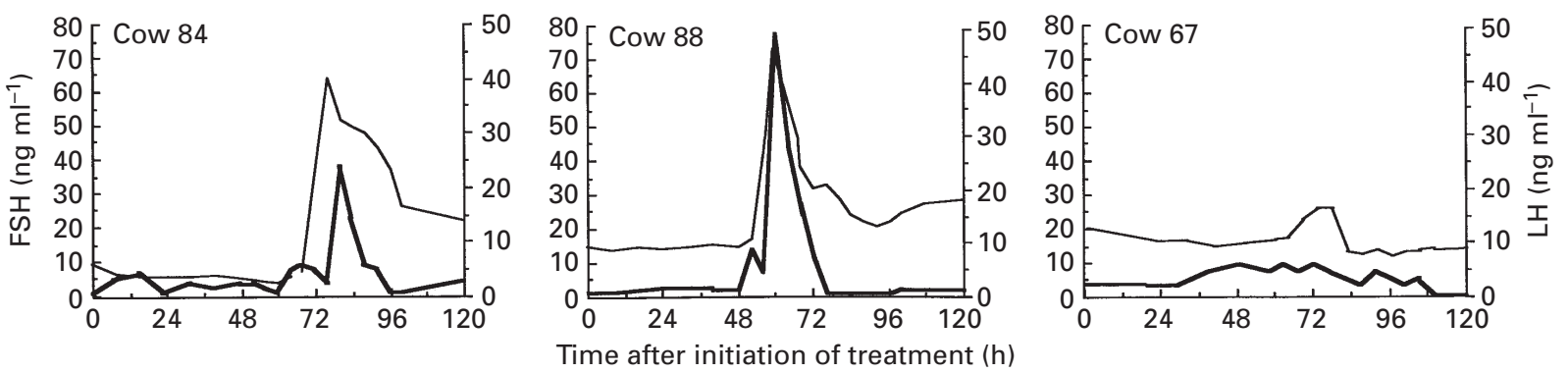

Fig. 3. FSH (-) and LH (-) concentrations in (a) a control cow and cows treated with (b) $50 \mu \mathrm{g}$ porcine LH (pLH) $\mathrm{h}^{-1}$ or (c) $100 \mu \mathrm{g}$ $\mathrm{pLH} \mathrm{h}^{-1}$. (a) Cow 80 ovulated the third postpartum dominant follicle; (b) cow 70 had an LH surge but failed to ovulate until the second postpartum dominant follicle; cow 86 had no LH surge and failed to ovulate until the fourth postpartum dominant follicle; (c) cow 84 ovulated the first postpartum dominant follicle after an LH surge; cow 88 had an LH surge but ovulated the fourth dominant follicle post partum; and cow 67 had no LH surge and ovulated the third postpartum dominant follicle.

(Savio et al., 1993). Taken together, these results confirm the key role of LH in determining the growth and capacity for oestrogen production of the dominant follicle in cows. In the present study, LH and oestradiol concentrations were significantly increased in cows given pLH pulses compared with control cows, confirming the role of $\mathrm{LH}$ pulses in stimulating oestradiol production from prolonged dominant follicles (Bigelow and Fortune, 1998).

Monitoring ovarian follicles using ultrasonography does not give precise information on the functional state of the follicle. In this study, a dominant follicle was defined as dominant when it was at least $2 \mathrm{~mm}$ greater in diameter than any other follicle present on either ovary, and at least $10 \mathrm{~mm}$ in diameter. It is possible that once the follicle becomes dominant, it is already LH-dependent and the time required to confirm its dominance by size deviation using ultrasound scanning could have been detrimental to its subsequent developmental fate, in that apoptosis of a significant number of granulosa cells may have irreversibly started the atretic process. It may be necessary to start pLH infusion before ultrasound confirmation of the presence of the first postpartum dominant follicle to induce successful final maturation and ovulation of the first dominant follicle. Further work is necessary to correlate the size at which the follicle becomes dominant with oestrogen activity and other biochemical markers (Mihm et al., 1997) and the extent of pycnosis of granulosa cells, as it is not possible to define the state of atresia of follicles on the basis of ovarian scanning alone, to allow more precise timing of LH pulse infusions and induce more consistent responses.

In year 1 , pulsing cows with $50 \mu \mathrm{g} \mathrm{pLHh} \mathrm{h}^{-1}$ altered follicular dynamics, whereas in year 2 it did not. The reason for this difference is not clear since there was no difference in LH pulse frequency between controls in year 1 and 2, although body condition score was better in year 2 . Treatment of cows during the early dominance period of the first dominant follicle with $50 \mu \mathrm{g} \mathrm{pLH} \mathrm{h}{ }^{-1}$ did not induce ovulation. This may be due to inadequate $\mathrm{LH}$ pulse amplitude $\left(1.8 \pm 0.19\right.$ and $1.7 \pm 0.14 \mathrm{ng} \mathrm{m}^{-1}$ on days 0 and 2 of infusion) after this treatment compared with cows in the $100 \mu \mathrm{g} \mathrm{LH} \mathrm{h}{ }^{-1}$ group $\left(3.4 \pm 0.05\right.$ and $4.0 \pm 0.75 \mathrm{ng} \mathrm{ml}^{-1}$ on days 0 and 2 of infusion). Infusion of $100 \mu \mathrm{g} \mathrm{pLH} \mathrm{h}{ }^{-1}$ resulted in ovulation of the first dominant follicle post partum in three of seven cows. The apparent reason for failure of the first dominant follicle to ovulate in the remaining cows in this treatment group was the inability of this LH pulse pattern to stimulate significant oestradiol production from the first postpartum dominant follicle. Inadequate oestradiol 
(a)

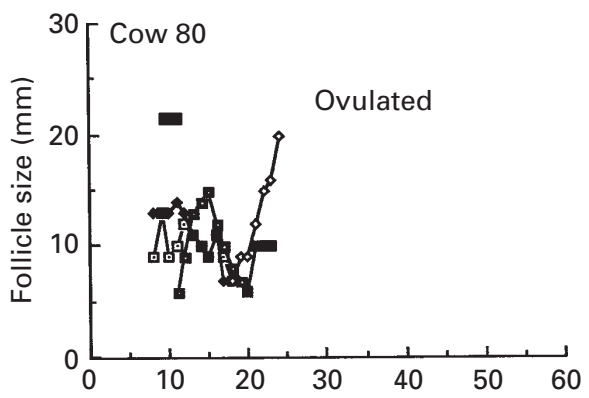

(b)
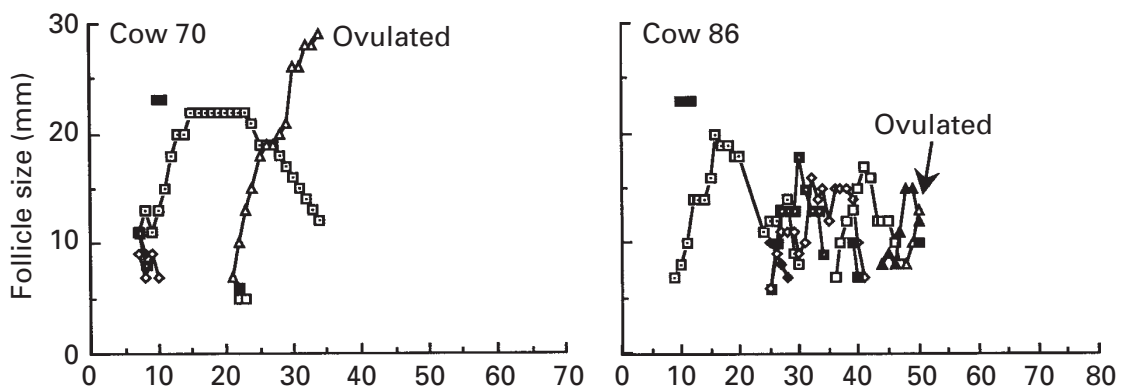

(c)
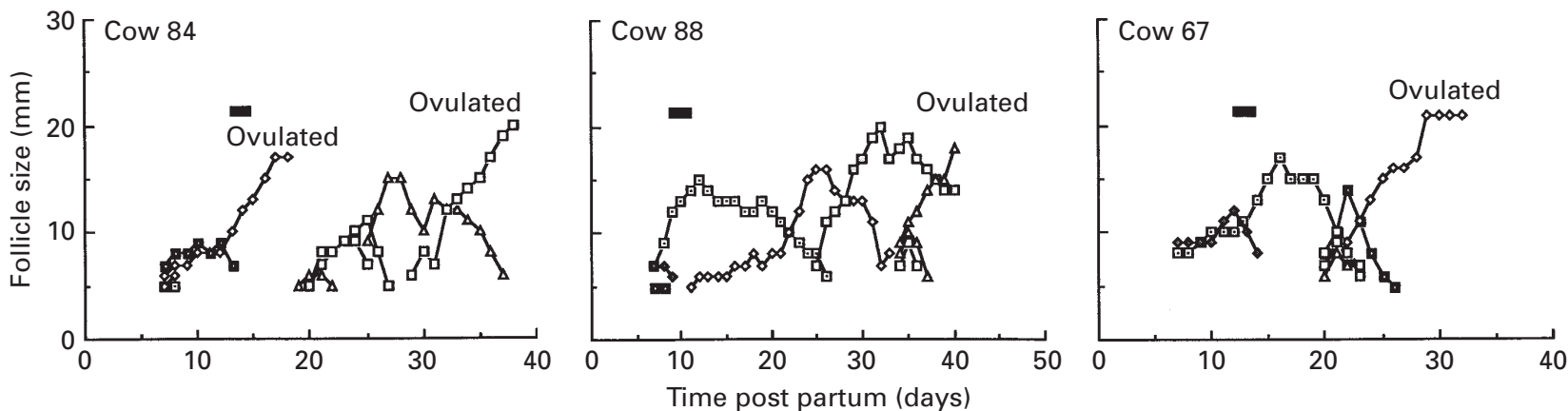

Fig. 4. Follicular growth in (a) a control cow and cows treated with (b) $50 \mu \mathrm{g}$ porcine LH (pLH) h ${ }^{-1}$ or (c) $100 \mu \mathrm{g}$ pLH h ${ }^{-1}$. (a) Cow 80 ovulated the third postpartum dominant follicle; (b) cow 70 had an LH surge but failed to ovulate until the second dominant follicle; cow 86 had no LH surge and failed to ovulate until the fourth postpartum dominant follicle; (c) cow 84 ovulated the first postpartum dominant follicle after an LH surge; cow 88 had an LH surge but ovulated the fourth dominant follicle post partum; and cow 67 had no LH surge and ovulated the third postpartum dominant follicle. The solid bars ( $\mathbf{\square})$ indicate period of saline or pLH infusion.

production by the first postpartum dominant follicle could have been due to inadequate $\mathrm{pLH}$ concentrations, use of porcine rather than bovine $\mathrm{LH}$, or delayed initiation of infusion relative to onset of functional dominance. Hence, low or inadequate LH pulse frequency in cows (early postpartum period of beef cows, before puberty or the luteal phase of cyclic cows) results in decreased oestradiol concentrations (Stagg et al., 1995), lack of positive feedback, and atresia rather than ovulation of the dominant follicle.

In this study, there was no detectable effect of $\mathrm{pLH}$ infusion on FSH concentrations. Detection of FSH increases, associated with follicle emergence in this study, is consistent with previous studies (Crowe et al., 1998; Stagg et al., 1998), which reported that recurrent increases in FSH concentrations occur before emergence of each wave of follicle growth during the postpartum anoestrous period of beef cows. These findings disagree with other studies in which FSH concentrations did not vary during postpartum anoestrus (Moss et al., 1985; Leung et al., 1986; Short et al.,
1990). The failure to detect FSH increases in these studies may reflect the inadequacy of the bovine FSH assays available or inadequate frequency of blood samples.

In Expt 2, normal oestrous cycles occurred in the three cows that ovulated in response to $\mathrm{pLH}$ infusion during the growing phase of the first dominant follicle post partum. This is in agreement with data from dairy cows that have an oestrous cycle of normal duration after ovulation of a dominant follicle on or before day 15 post partum (Savio et al., 1990). The remaining cows that did not ovulate in response to $\mathrm{LH}$ treatment in the present study had a predominance of short oestrous cycles after the first ovulation. This finding is consistent with other studies which indicate that the first ovulation post partum after day 20 in beef cows is usually followed by a short oestrous cycle (Lamming et al., 1981; Murphy et al., 1990; Crowe et al., 1993; Stagg et al., 1995).

In conclusion, this study demonstrates that infusing cows with hourly pLH pulses in the early dominance period of the 
first dominant follicle either increased the maximum size of the first dominant follicle and increased its duration of dominance or resulted in ovulation of that follicle. It also postponed the first day of dominance of the second dominant follicle by approximately 6 days. Hourly infusion with $50 \mu \mathrm{g}$ pLH induced an LH surge in half of the cows. However, none of these cows ovulated the first dominant follicle post partum. The cows infused with $\mathrm{pLH}$ showed more LH pulses and higher oestradiol concentrations than the control cows. There was no difference in FSH concentrations between treatments. Hourly infusion with $100 \mu \mathrm{g}$ pLH demonstrated that the first postpartum dominant follicle was capable of producing adequate oestradiol to induce an LH surge and ovulation if exposed to the appropriate LH pulse frequency and amplitude in the early dominant period. These results support the crucial role of LH pulses in ovulation of dominant follicles during the early postpartum period of beef cows nursing calves.

The authors acknowledge Philip Joumand, Argene Biosoft, France, for providing progesterone monoclonal antibody (Pi 531b; lot 08), J. Roser, Department of Animal Science, University of California, Davis, CA, USA, for LH monoclonal antibody, the NHPP of the NIH for provision of FSH antisera (AFP - C5288113) and FSH for iodination (AFP - 4177A), and D. Bolt, USDA, Beltsville, MD, USA, for providing bovine FSH standard. This research was supported by EU AAIR funds (Grant No. 92/1124).

\section{References}

Bigelow KL and Fortune JE (1998) Characteristics of prolonged dominant versus control follicles: follicle cell numbers, steroidogenic capabilities and messenger ribonucleic acid for steroidogenic enzymes Biology of Reproduction 58 1241-1249

Cooke DJ, Crowe MA and Roche JF (1997) Circulating FSH isoform patterns during recurrent increases in FSH throughout the oestrous cycle of heifers Journal of Reproduction and Fertility 110 339-345

Crowe MA, Goulding D, Baguisi A, Boland MP and Roche JF (1993) Induced ovulation of the first postpartum dominant follicle in beef suckler cows using a GnRH analogue Journal of Reproduction and Fertility 99 551-555

Crowe MA, Padmanabhan V, Hynes N, Sunderland SJ, Enright WJ, Beitins IZ and Roche JF (1997) Validation of a sensitive radioimmunoassay to measure serum follicle-stimulating hormone in cattle: correlation with biological activity Animal Reproduction Science 48 123-136

Crowe MA, Padmanabhan V, Mihm M, Beitins IZ and Roche JF (1998) Resumption of follicular waves in beef cows is not associated with periparturient changes in follicle-stimulating hormone heterogeneity despite major changes in steroid and luteinizing hormone concentrations Biology of Reproduction 58 1445-1450

Fortune JE (1986) Bovine theca and granulosa cells interact to promote androgen production Biology of Reproduction 35 292-299

Gong JG, Baxter G, Bramley TA and Webb R (1997) Enhancement of ovarian follicle development in heifers by treatment with recombinant bovine somatotrophin: a dose response study Journal of Reproduction and Fertility 101 91-97

Ireland JJ and Roche JF (1982) Development of antral follicles in cattle after prostaglandin-induced luteolysis: changes in serum hormones, steroids in follicle fluid and gonadotrophin receptors Endocrinology 111 2077-2086

Lamming GE, Wathes DC and Peters AR (1981) Endocrine patterns of the post-partum cow Journal of Reproduction and Fertility Supplement 30 155-170

Leung K, Padmanabhan V, Spicer LJ, Tucker HA, Short RE and Convey EM (1986) Relationship between pituitary GnRH-binding sites and pituitary release of gonadotrophins in post-partum beef cows Journal of Reproduction and Fertility 76 53-63

Merriam GR and Wachter KW (1982) Algorithms for the study of episodic hormone secretion American Journal of Physiology 243 E310-E318

Mihm M, Good TEM, Ireland JLH, Ireland JJ, Knight PG and Roche JF (1997) Decline in serum follicle-stimulating hormone concentrations alters key intrafollicular growth factors involved in selection of the dominant follicle in heifers Biology of Reproduction 57 1328-1337

Moss GE, Parfet JR, Marvin CA, Allrich RD and Diekman MA (1985) Pituitary concentrations of gonadotropins and receptors for $\mathrm{GnRH}$ in suckled beef cows at various intervals after calving Journal of Animal Science 60 285-293

Murphy MG, Boland MP and Roche JF (1990) Pattern of follicular growth and resumption of ovarian activity in post-partum beef suckler cows Journal of Reproduction and Fertility 90 523-533

Peters AR, Pimentle MG and Lamming GE (1985) Hormone responses to exogenous GnRH pulses in post-partum dairy cows Journal of Reproduction and Fertility 75 551-565

Prendiville DJ, Enright WJ, Crowe MA, Finnerty M, Hynes N and Roche JF (1995) Immunization of heifers against gonadotropin-releasing hormone: antibody titers, ovarian function, body growth, and carcass characteristics Journal of Animal Science 73 2382-2389

Rahe CH, Ownes RE, Fleeger JL, Newton HL and Harmes PG (1980) Patterns of plasma luteinizing hormone in the cyclic cow: dependency upon the peroid of the cycle Endocrinology 107 498-503

Roche JF, Crowe MA and Boland MP (1992) Postpartum anoestrus in dairy and beef cows Animal Reproduction Science 28 371-378

Ronayne E and Hynes N (1990) Measurement of plasma progesterone concentrations by extraction and non-extraction radioimmunoassays Irish Journal of Agriculture Research 29 109-115

Savio JD, Boland MP and Roche JF (1990) Development of dominant follicles and length of ovarian cycles in post-partum dairy cows Journal of Reproduction and Fertility 88 581-591

Savio JD, Thatcher WW, Morris GR, Entwistle K, Drost M and Mattiacci MR (1993) Effects of induction of low plasma progesterone concentrations with a progesterone-releasing intravaginal device on follicular turnover and fertility in cattle Journal of Reproduction and Fertility 98 77-84

Short RE, Bellows RA, Staigmiller RB, Berardinelli JG and Custer EE (1990) Physiological mechanisms controlling anestrus and infertility in postpartum beef cattle Journal of Animal Science 68 799-816

Snedecor PA and Cochran WG (1980) Statistical Methods 7th Edn pp 215-237 Iowa State University Press, Ames

Stagg K, Diskin MG, Sreenan JM and Roche JF (1995) Follicular development in long-term anoestrous suckler beef cows fed two levels of energy post partum Animal Reproduction Science 38 49-61

Stagg K, Spicer LJ, Sreenan JM, Roche JF and Diskin MG (1998) Effect of calf isolation on follicular wave dynamics, gonadotropin and metabolic hormone changes, and interval to first ovulation in beef cows fed either of two energy levels post partum Biology of Reproduction 59 777-783

Stock AE and Fortune JE (1993) Ovarian follicular dominance in cattle: relationship between prolonged growth of the ovulatory follicle and endocrine parameters Endocrinology 132 1108-1114

Swinscow TDV (1996) Statistics at Square One 9th Edn pp 86-91 Revised by MJ Campbell. BMJ Publishing Group, London

Williams GL (1990) Suckling as a regulator of postpartum rebreeding in cattle: a review Journal of Animal Science 68 831-852

Williams GL and Griffith MK (1995) Sensory and behavioural control of gonadotrophin secretion during suckling-mediated anovulation in cows Journal of Reproduction and Fertility Supplement 49 463-475 